\title{
Front Matter: Volume 9341
}

, "Front Matter: Volume 9341," Proc. SPIE 9341, Bioinspired, Biointegrated, Bioengineered Photonic Devices III, 934101 (15 April 2015); doi:

10.1117/12.2192924

SPIE. Event: SPIE BiOS, 2015, San Francisco, California, United States 


\section{Bioinspired, Biointegrated, Bioengineered Photonic Devices III}

Luke P. Lee

John A. Rogers

Seok Hyun Andy Yun

Editors

7-8 February 2015

San Francisco, California, United States

Sponsored and Published by

SPIE 
The papers included in this volume were part of the technical conference cited on the cover and title page. Papers were selected and subject to review by the editors and conference program committee. Some conference presentations may not be available for publication. The papers published in these proceedings reflect the work and thoughts of the authors and are published herein as submitted. The publisher is not responsible for the validity of the information or for any outcomes resulting from reliance thereon.

Please use the following format to cite material from this book:

Author(s), "Title of Paper," in Bioinspired, Biointegrated, Bioengineered Photonic Devices III, edited by Luke P. Lee, John A. Rogers, Seok Hyun Andy Yun, Proceedings of SPIE Vol. 9341 (SPIE, Bellingham, WA, 2015) Article CID Number.

ISSN: 1605-7422

ISBN: 9781628414318

Published by

SPIE

P.O. Box 10, Bellingham, Washington 98227-0010 USA

Telephone +1 3606763290 (Pacific Time) · Fax +1 3606471445

SPIE.org

Copyright (C) 2015, Society of Photo-Optical Instrumentation Engineers.

Copying of material in this book for internal or personal use, or for the internal or personal use of specific clients, beyond the fair use provisions granted by the U.S. Copyright Law is authorized by SPIE subject to payment of copying fees. The Transactional Reporting Service base fee for this volume is $\$ 18.00$ per article (or portion thereof), which should be paid directly to the Copyright Clearance Center (CCC), 222 Rosewood Drive, Danvers, MA 01923. Payment may also be made electronically through CCC Online at copyright.com. Other copying for republication, resale, advertising or promotion, or any form of systematic or multiple reproduction of any material in this book is prohibited except with permission in writing from the publisher. The CCC fee code is $1605-7422 / 15 / \$ 18.00$.

Printed in the United States of America.

Publication of record for individual papers is online in the SPIE Digital Library.

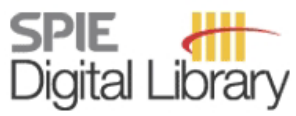

SPIEDigitalLibrary.org

Paper Numbering: Proceedings of SPIE follow an e-First publication model, with papers published first online and then in print. Papers are published as they are submitted and meet publication criteria. A unique citation identifier (CID) number is assigned to each article at the time of the first publication. Utilization of CIDs allows articles to be fully citable as soon as they are published online, and connects the same identifier to all online, print, and electronic versions of the publication. SPIE uses a six-digit CID article numbering system in which:

- The first four digits correspond to the SPIE volume number.

- The last two digits indicate publication order within the volume using a Base 36 numbering

system employing both numerals and letters. These two-number sets start with 00, 01, 02, 03, 04, $05,06,07,08,09,0 A, 0 B \ldots$. OZ, followed by 10-1Z, 20-2Z, etc.

The CID Number appears on each page of the manuscript. The complete citation is used on the first page, and an abbreviated version on subsequent pages. 


\title{
Contents
}

\author{
$\checkmark$ Authors \\ vii Conference Committee
}

\section{BIOENGINEERED LIGHT SOURCES}

9341 OF Micro-patterned quantum dots excitation for cellular microarray imaging (Invited Paper) [9341-14]

BIOINSPIRED PHOTONICS

9341 OG Analysis of quasi-periodic pore-network structure of centric marine diatom frustules [9341-15]

$9341 \mathrm{OH}$ Effects of ICG concentration on the optical properties of erythrocyte-derived nano-vectors [9341-16]

9341 0J Natural production of biological optical systems [9341-18]

9341 OK Untwisting the polarization properties of light reflected by scarab beetles [9341-19]

$9341 \mathrm{OL}$ Progress towards elucidating the structure-function relationships of a natural nanoscale photonic device in cuttlefish chromatophores (Invited Paper) [9341-20]

POSTER SESSION

9341 OR Biocompatible optical needle array for antibacterial blue light therapy [9341-26] 
Proc. of SPIE Vol. $9341934101-4$

Downloaded From: https://www.spiedigitallibrary.org/conference-proceedings-of-spie on 26 Apr 2023 Terms of Use: https://www.spiedigitallibrary.org/terms-of-use 


\title{
Authors
}

Numbers in the index correspond to the last two digits of the six-digit citation identifier (CID) article numbering system used in Proceedings of SPIE. The first four digits reflect the volume number. Base 36 numbering is employed for the last two digits and indicates the order of articles within the volume. Numbers start with 00, 01, 02, 03, 04, 05, 06, 07, 08, 09, 0A, 0B...0Z, followed by 10-1Z, 20-2Z, etc.

\author{
Alvarez, Christine E., OG \\ An, Jeesoo, OR \\ Anvari, Bahman, $\mathrm{OH}$ \\ Bacon, Danielle, $\mathrm{OH}$ \\ Bahmani, Baharak, $\mathrm{OH}$ \\ Bell, George R. R., OL \\ Bhave, Gauri, OF \\ Burns, Joshua, $\mathrm{OH}$ \\ Choi, Seung Ho, OJ \\ Cohoon, Gregory A., OG \\ Deheyn, Dimitri D., OG \\ Deravi, Leila F., OL \\ Finlayson, Ewan D., OK \\ Goth, Will, OR \\ Guimarães, Caio, OR \\ Hanlon, Roger T., OL \\ Hildebrand, Mark, OG \\ Hu, Evelyn L., OL \\ Humar, Matjaz, OR \\ Jia, Wangcun, $\mathrm{OH}$ \\ Kieu, Khanh, OG \\ Kim, Young L., OJ \\ Kuzirian, Alan M., OL \\ Lee, Youngkyu, OF \\ $\mathrm{Mac}$, Jenny, $\mathrm{OH}$ \\ Magyar, Andrew P., OL \\ Mäthger, Lydia M., OL \\ McDonald, Luke T., OK \\ Meyers, Keith, OG \\ Nelson, J. S., $\mathrm{OH}$ \\ $\mathrm{Ng}$, Elaine, OF \\ Norwood, Robert A., OG \\ Nuñez, Vicente, $\mathrm{OH}$ \\ Parker, Kevin Kit, OL \\ Sheehy, Sean P., OL \\ Sun, Victor, $\mathrm{OH}$ \\ Tang, Jack, $\mathrm{OH}$ \\ Vukusic, Peter, OK \\ Vullev, Valentine, $\mathrm{OH}$ \\ Yun, Andy, OR \\ Zhang, John X.J., OF
}


Proc. of SPIE Vol. $9341934101-6$

Downloaded From: https://www.spiedigitallibrary.org/conference-proceedings-of-spie on 26 Apr 2023 Terms of Use: https://www.spiedigitallibrary.org/terms-of-use 


\title{
Conference Committee
}

\author{
Symposium Chairs
}

James G. Fujimoto, Massachusetts Institute of Technology

(United States)

R. Rox Anderson, Wellman Center for Photomedicine, Massachusetts General Hospital (United States) and Harvard School of Medicine (United States)

Program Track Chairs

Paras N. Prasad, University at Buffalo (United States)

Dan V. Nicolau, McGill University (United States)

Conference Chairs

Luke P. Lee, University of California, Berkeley (United States)

John A. Rogers, University of Illinois at Urbana-Champaign (United States)

Seok Hyun Andy Yun, Harvard University (United States)

Conference Program Committee

David Erickson, Cornell University (United States)

Malte C. Gather, University of St. Andrews (United Kingdom)

Viktoria Greanya, Defense Threat Reduction Agency (United States)

Hongrui Jiang, University of Wisconsin-Madison (United States)

Session Chairs

1 Keynote Session

Hongrui Jiang, University of Wisconsin-Madison (United States)

2 Biomimetic Photonics

Vikłoria Greanya, Defense Threat Reduction Agency (United States)

3 Wearable Photonic Devices

Hongrui Jiang, University of Wisconsin-Madison (United States)

4 Bioengineered Light Sources

Malte C. Gather, University of St. Andrews (United Kingdom) 
5 Bioinspired Photonics

Viktoria Greanya, Defense Threat Reduction Agency (United States)

6 Biointegrated Devices

David Erickson, Cornell University (United States) 